\title{
Rare cause of abdominal angina
}

\author{
Diana M Oliveira, Inês Nunes, Patrícia Dias
}

Department of Internal Medicine, Centro Hospitalar e Universitário de Coimbra, Coimbra, Portugal

\section{Correspondence to} Dr Diana M Oliveira, difilipa_oliveira@hotmail.com

Accepted 31 July 2019

\section{DESCRIPTION}

The median arcuate ligament syndrome (MALS) or Dunbar syndrome was first described in 1963 by Harjola ${ }^{1}$ and 2 years later, Dunbar et $a l^{2}$ reported the first surgically treated patients. It is a rare condition that results from the compression of the celiac axis, causing symptoms like postprandial abdominal pain, nausea, epigastric bruit and unintentional weight loss. ${ }^{3}$ It is more common in women in their fourth and fifth decades of life and symptoms can persist for 3 months to 10 years. ${ }^{3-5}$

We present a case of a 77-year-old woman, with hypertension and severe mitral stenosis, who came to the emergency room for epigastric pain, with a severity of 8 on 10 on a pain scale of $0-10$. She reported postprandial episodic epigastric pain and nausea without vomiting since the age of 45 , with

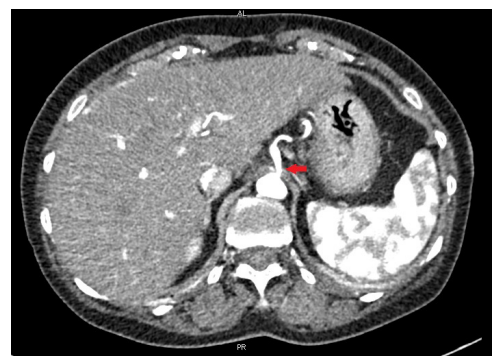

Figure 1 Abdominal $\mathrm{CT}$ angiography of the abdomen demonstrating compression of the celiac axis (arrow) due to obstruction by the median arcuate ligament, in the transversal plane.

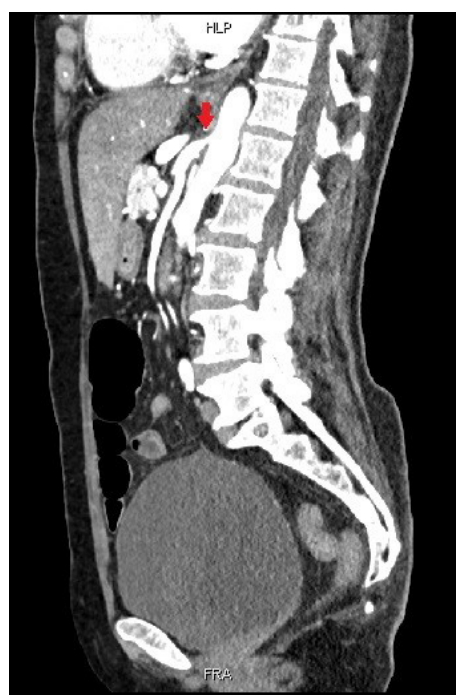

Figure 2 Abdominal $\mathrm{CT}$ angiography of the abdomen demonstrating compression of the celiac axis (arrow) due to obstruction by the median arcuate ligament, in the sagittal plane.

\section{Learning points}

- Abdominal pain includes an extensive range of differential diagnoses and therefore, deep research is needed before we reach the correct diagnosis.

- Median arcuate ligament syndrome is rare, and as a diagnosis of exclusion, the patient may endure months to years of recurrent abdominal pain without knowledge of aetiology.

- In patients with abdominal pain that persists after medical therapy, it may be useful to perform a vascular investigation.

spontaneous resolution. The patient had been evaluated in an outpatient clinic for these complaints in the previous years, with an extensive evaluation of her gastrointestinal tract (upper and lower endoscopy) and evaluation of gall bladder diseases with multiple abdominal ultrasounds. Blood tests and abdominal ultrasound were unremarkable. An abdominal CT angiography was performed because she had no pain relief with analgesic therapy. High-grade stenosis of the celiac axis origin due to extrinsic compression by the median arcuate ligament was identified (figures 1 and 2). Due to the recurring pattern and characteristics of the abdominal pain, and to the lack of evidence of alternative diagnosis from the investigations performed, MALS was assumed. There is currently no medical treatment for this condition. ${ }^{3}$ We adopted a watchful waiting approach attending to the age and comorbidities of the patient. Surgery is the only effective approach; however, celiac angioplasty or endovascular stenting can be considered. ${ }^{35}$

Contributors DMO: wrote the article with the support of IN. PD: helped supervise the work and conceived the original idea.

Funding The authors have not declared a specific grant for this research from any funding agency in the public, commercial or not-for-profit sectors.

Competing interests None declared.

Patient consent for publication Obtained.

Provenance and peer review Not commissioned; externally peer reviewed.

\section{REFERENCES}

1 Harjola PT. A rare obstruction of the celiac artery. Ann Chir Gynaecol Fenn 1963;52:547-50.

2 Dunbar JD, Molnar W, Beman FF, Marable SA, et al. Compression of the celiac trunk and abdominal angina. Am J Roentgenol Radium Ther Nucl Med 1965;95:731-44.

3 Sunkara T, Caughey ME, Zhen KC, CaiZhen K, et al. Dunbar syndrome-a rare cause of foregut ischemia. J Clin Diagn Res 2017;11.

4 Wu E. Median arcuate ligament syndrome. J Diagn Med Sonogr 2019:35:141-5.

5 Kim EN, Lamb K, Relles D, et al. Median arcuate ligament syndromereview of this rare disease. JAMA Surg 2016;151:471-7. 


\section{Images in...}

Copyright 2019 BMJ Publishing Group. All rights reserved. For permission to reuse any of this content visit https://www.bmj.com/company/products-services/rights-and-licensing/permissions/

BMJ Case Report Fellows may re-use this article for personal use and teaching without any further permission.

Become a Fellow of BMJ Case Reports today and you can:

- Submit as many cases as you like

- Enjoy fast sympathetic peer review and rapid publication of accepted articles

Access all the published articles

Re-use any of the published material for personal use and teaching without further permission

Customer Service

If you have any further queries about your subscription, please contact our customer services team on +44 (0) 2071111105 or via email at support@bmj.com.

Visit casereports.bmj.com for more articles like this and to become a Fellow 